\title{
Green Marketing Strategies of Restaurants in Nueva Ecija, Philippines
}

\author{
Renato Virola
}

Nueva Ecija University of Science and Technology, Cabanatuan City, Philippines

\begin{abstract}
Businesses today have been quick to adopt environmental management practices and implement green marketing strategies that focus on transforming such businesses to become eco-friendly entities.

This research aimed at finding out how restaurants in Nueva Ecija use the concept of green marketing, and it examined its significant impact in their present undertakings. Furthermore, this research analyzed the green marketing strategies used by the restaurants and noted the challenges coupled in the implementation of such strategies.

The respondents of the study were the owners/managers of fifteen (15) restaurants in Nueva Ecija. Survey questionnaire was the main instrument used by the researcher in conducting this study. The study revealed that the main reason for restaurant owners/managers on adopting green marketing strategies is to show their corporate social responsibilities. The top green marketing strategies practiced by the restaurants are the use of paper boxes in take-out orders and the minimal use of straws and plastic cups.However, the top challenge encountered by the restaurant owners/managers in adopting green marketing is primarily on the costs involved in implementing such strategies. The researcher recommended that each restaurant management should have a comprehensive marketing plan towards the effectiveness of implementing green marketing strategies.
\end{abstract}

Keywords- Environment, Green Marketing and Green Marketing Strategy

\section{INTRODUCTION}

Conserving environment has increasingly becoming an issue in the business world and more and more companies are getting attentive. Taking care of the environment is seen by the companies as a responsibility not imposed by outside forces but dictated by conscience as the best practice of giving back to society, people and communities. Companies now have begun to adopt the concept of Green Marketing as their strategies in doing their endeavor and as value addition that might offer them competitive advantage in business arena.
Green Marketing refers to the holistic marketing concept that focuses on transforming such business to become eco-friendly entity. It turns businesses' production/operations, marketing, consumption and disposal of products happen in a manner that is less destructive to the environment (Satpal, 2013). According to Domingo (2018) marketing plays a very important role in the organization's success; it is a must to every organization to consider strategizing their different marketing practices. Thus, utilizing green marketing, as another marketing strategy is timely and relevant in promoting businesses today.

Restaurants in Nueva Ecija simply start to embrace the transformation and gear forward to achieve a greener image. Restaurant owners do not only exert too much effort in managing business finances, providing mouth-watery foods and making more delighted customers. Today, they are also focused on performing their social responsibilities through the implementation of green marketing.

This research aimed at finding out how restaurants in Nueva Ecija use the concept of green marketing and examined its significant impact in their present undertakings. Furthermore, this research analyzed the green marketing strategies used by the restaurants and noted the challenges coupled in the implementation of such strategies.

The outcome of this paper may trigger the minds of restaurant managers to give an idea for improving their green marketing strategies which will give them a way to be better and more effective in implementing their green marketing strategies.

\section{METHODOLOGY}

The respondents of the study were the 15 owners/managers of selected restaurants in Nueva Ecija. Survey questionnaire was the main instrument used by the researcher in conducting this study. Researcher used structured questionnaire and a five point likert scale for assessing the green marketing strategies of the restaurants. 


\begin{tabular}{|c|c|c|}
\hline \multicolumn{3}{|c}{ Table.1: Responses } \\
Ranges & $\begin{array}{c}\text { Reasons for Using Green } \\
\text { Marketing, Benefits, } \\
\text { Challenges and Coping } \\
\text { Mechanism }\end{array}$ & $\begin{array}{c}\text { Green } \\
\text { Marketing } \\
\text { Strategies }\end{array}$ \\
\hline $4.21-5.00$ & Strongly Agree & Always \\
\hline $3.41-4.20$ & Agree & Often \\
\hline $2.61-3.40$ & Moderately Agree & Sometimes \\
\hline $1.81-2.60$ & Dis agree & Seldom \\
\hline $1.00-1.80$ & Strongly Disagree & Never \\
\hline
\end{tabular}

\section{RESULTS AND DISCUSSIONS}

Table.2: Reasons for Adopting Green Marketing Strategies

\begin{tabular}{|l|c|c|c|}
\hline \multicolumn{1}{|c|}{ Reasons } & WM & VI & Rank \\
\hline $\begin{array}{l}\text { 1. Opportunities or } \\
\text { competitive advantage }\end{array}$ & 4.20 & $\mathrm{~A}$ & 2 \\
\hline $\begin{array}{l}\text { 2. Corporate social } \\
\text { responsibilities }\end{array}$ & 4.33 & $\mathrm{SA}$ & 1 \\
\hline 3. Government pressure & 3.87 & $\mathrm{~A}$ & 3.5 \\
\hline 4. Competitive pressure & 3.87 & $\mathrm{~A}$ & 3.5 \\
\hline $\begin{array}{l}\text { 5. Cost or profit issues } \\
\text { concerns }\end{array}$ & 3.53 & $\mathrm{~A}$ & 5 \\
\hline
\end{tabular}

As to the reasons for adopting green marketing strategies, restaurant owners/managers are motivated to use the green marketing strategy to show their corporate social responsibilities. Restaurants believed that they have a moral obligation to be more socially responsible.

\section{Table.3: Benefits of Green Marketing}

\begin{tabular}{|l|c|c|c|}
\hline \multicolumn{1}{|c|}{ Benefits } & WM & VI & Rank \\
\hline $\begin{array}{l}\text { 1. Green marketing can } \\
\text { enhance } \\
\text { environmental awarenes of } \\
\text { green products. }\end{array}$ & 4.33 & SA & 5.5 \\
\hline $\begin{array}{l}\text { 2. Through green marketing, } \\
\text { the restaurants can obtain a } \\
\text { green reputation and brand } \\
\text { image and, it can attract a } \\
\text { new and larger client base. }\end{array}$ & 4.27 & SA & 8.5 \\
\hline $\begin{array}{l}\text { 3. Having good } \\
\text { environmental credentials } \\
\text { can provide a competitive } \\
\text { edge when tendering for } \\
\text { contracts. }\end{array}$ & 4.33 & SA & 5.5 \\
\hline $\begin{array}{l}\text { 4. It can gain public approval } \\
\text { and can cut costs by using } \\
\text { green marketing. }\end{array}$ & 4.27 & SA & 8.5 \\
\hline $\begin{array}{l}\text { 5. It helps in enjoying } \\
\text { competitive advantage. }\end{array}$ & 4.53 & SA & 1 \\
\hline
\end{tabular}

\section{Advertising}

green

\begin{tabular}{l|l|l|}
4.40 & SA & 3
\end{tabular}

initiatives effectively can

acquire a greater market

share.

7. Including green marketing practices in overall corporate message can attract new customers.

\section{Portraying}

environmental-friendly

business image through advertising and sales promotion can keep loyal stakeholder groups.

9. Using green marketing for positive positioning can project a corporate social responsibility image.

As to the benefits, green marketing, indeed, helps restaurants in accessing the new markets and enjoying competitive advantage.

Table.4: Green Marketing Strategies Used by Restaurants in Nueva Ecija

\begin{tabular}{|l|c|c|c|}
\hline \multicolumn{1}{|c|}{ Strategies } & WM & VI & Rank \\
\hline $\begin{array}{l}\text { 1. Using paper boxes and } \\
\text { paper bags in take-out orders }\end{array}$ & 4.33 & $\mathrm{~A}$ & 1.5 \\
\hline $\begin{array}{l}\text { 2. Minimizing the use of } \\
\text { straws and plastic cups }\end{array}$ & 4.33 & $\mathrm{~A}$ & 1.5 \\
\hline $\begin{array}{l}\text { 3. Is suing napkins that are } \\
\text { from recycled papers (brown } \\
\text { tissue) }\end{array}$ & 3.60 & $\mathrm{~S}$ & 7 \\
\hline $\begin{array}{l}\text { 4. Using reusable utensils } \\
\text { rather than disposable ones }\end{array}$ & 4.07 & $\mathrm{O}$ & 4 \\
\hline $\begin{array}{l}\text { 5. Giving freebies/items to } \\
\text { promote the conservation of } \\
\text { environment. }\end{array}$ & 3.47 & $\mathrm{O}$ & 8 \\
\hline 6. Giving eco bags for free & 3.40 & $\mathrm{~S}$ & 9 \\
\hline $\begin{array}{l}\text { 7. Serving proper portion of } \\
\text { food to reduce food waste }\end{array}$ & 4.20 & $\mathrm{O}$ & 3 \\
\hline $\begin{array}{l}\text { 8. Non-smoking policy } \\
\text { (non-smoking } \\
\text { property) for indoor air } \\
\text { quality }\end{array}$ & 3.87 & $\mathrm{O}$ & 5.5 \\
\hline $\begin{array}{l}\text { 9. Placing green live plants } \\
\text { for the quality of indoor air }\end{array}$ & 3.87 & $\mathrm{O}$ & 5.5 \\
\hline
\end{tabular}

As to green marketing strategies, restaurant owners/managers initiated the use of paper boxes in takeout orders and the minimal use of straws and plastic cups. 
This is due to the implementation of Ordinance No. 0152012 of the city government of Cabanatuan, in Nueva Ecija, by which non-biodegradable plastic bags are banned; thus, people shall have to use eco-bags or baskets. The measure also prohibited selling, giving and offering plastics in establishments like restaurants and the likes (Galang, 2013).

Table.5: Challenges Faced by the Restaurant Owners/Managers in Implementing Green Marketing.

\begin{tabular}{|l|c|c|c|}
\hline \multicolumn{1}{|c|}{ Challenges } & WM & VI & Rank \\
\hline $\begin{array}{l}\text { 1. Majority of the people are } \\
\text { not aware of the benefits of } \\
\text { green marketing. }\end{array}$ & 4.33 & S & 2.5 \\
\hline $\begin{array}{l}\text { 2. Product packaging requires } \\
\text { a recyclable and renewable } \\
\text { materials or elements which } \\
\text { are expensive. }\end{array}$ & 4.33 & S & 2.5 \\
\hline $\begin{array}{l}\text { 3. People often perceive that } \\
\text { green marketing is just a } \\
\text { gimmick. }\end{array}$ & 4.13 & A & 6.5 \\
\hline $\begin{array}{l}\text { 4. Not all environmental labels } \\
\text { are used and interpreted } \\
\text { correctly. }\end{array}$ & 4.27 & S & 5 \\
\hline $\begin{array}{l}\text { 5. Green marketing depends on } \\
\text { technology and requires a } \\
\text { huge investment in Research } \\
\text { and Development. }\end{array}$ & 4.13 & A & 6.5 \\
\hline $\begin{array}{l}\text { 6. There are no concrete green } \\
\text { marketing plan. }\end{array}$ & 4.33 & S & 2.5 \\
\hline $\begin{array}{l}\text { 7. There is an increasing } \\
\text { number of competitors using } \\
\text { green marketing strategies }\end{array}$ & 4.07 & A & 8 \\
\hline $\begin{array}{l}\text { 8. There is an inconsistency of } \\
\text { the implementation of green } \\
\text { marketing strategy. }\end{array}$ & 4.33 & S & 2.5 \\
\hline
\end{tabular}

This table shows that the main challenges of green marketing are (1)majority of the people are not aware of the benefits of green marketing; (2)product packaging requires a recyclable and renewable materials or elements which are expensive; (3) there is no concrete green marketing plan; and (4) there is an inconsistency of the implementation of green marketing strategy.

\section{CONCLUSIONS AND RECOMMENDATIONS}

The study revealed that restaurant owners/managers in Nueva Ecija are motivated to adopt green marketing strategies to exhibit their corporate social responsibilities. Number one benefit of green marketing strategy is to gain competitive advantage over its competitors. In addition, the top green marketing strategies used by the restaurants are the use of paper boxes in take-out orders and the minimal use of straws and plastic cups. Meanwhile, top challenges encountered by the restaurant owners/managers in implementing green marketing are primarily on the costs involved in implementing green marketing strategies; no concrete green marketing plan; and inconsistency of the implementation of green marketing strategy. Thus, it is recommended that each restaurant management should have a marketing plan integrating the green marketing strategies. The effectiveness of their green marketing strategies should be evaluated by the management of the restaurants. Furthermore, another study prior to the effectiveness of green marketing strategies should be conducted.

\section{REFERENCES}

[1] Satpal Singh (2013). Green Marketing: Challenges and Strategy in the Changing Scenario. International Journal of Advanced Research in Management and Social Sciences. ISSN: 2278-623. Retrieved on $\begin{array}{llll}\text { September } & 1, & 2014 & \text { from }\end{array}$ http://garph.co.uk/IJARMSS/Dec2012/13.pdf

[2] Domingo, A.V. (2018).Product, pricing and promotional strategies of Restaurants in Nueva Ecija: An Assessment. International Journal of Advanced Engineering, Management and Science(ISSN: 24541311),4(11), 753-756. http://dx.doi.org/10.22161/ijaems.4.11.2

[3] Galang, Armand M. (2013). Cabanatuan City gets serious in no-plastic drive. Retrieved on September 2, 2014

from http://punto.com.ph/News/Article/17993/Volume-7$\underline{\text { No } 16 / \text { Headlines/function.session-start }}$ 